\title{
Research Regarding the Reputational Risk of Oil and Gas Companies Operating in Romania Business Market
}

\author{
Elena FLEAC $\breve{A}^{1)}$, Bogdan FLEAC $\breve{A}^{2 *}$ and Andreea DUMITRESCU ${ }^{3)}$ \\ 1) Faculty of Entrepreneurship, Business Engineering and Management, University POLITEHNICA of \\ Bucharest, Romania, 313 Splaiul Independentei, 060042, Bucharest, Romania. \\ ${ }^{*}$ Corresponding author, e-mail: bogdan.fleaca@upb.ro
}

Bulletin UASVM Horticulture 71(2) / 2014

Print ISSN 1843-5254, Electronic ISSN 1843-5394

DOI:10.15835/buasvmcn-hort:10436

\begin{abstract}
Romania's business environment has been through a series of changes, both politically and economically and therefore, the companies operating in this particular industry have been obliged to rapidly adapt to these new conditions in order to sustainably develop. In order to achieve compliance with these regulations, oil and gas companies have been required to spend copious amounts of resources, as the nature of their activity is very prone to environmental impact, which is, moreover, exacerbated by the relatively old age of their infrastructure. The paper aims to emphasize the importance of a correct assessment of reputational risk as it enables the enhancement of the organisation by strengthening the stakeholders' trust and securing business continuity in rather difficult circumstances in terms of health and safety, community and environmental concerns.
\end{abstract}

Keywords: reputation, risk management, sustainable development

\section{INTRODUCTION}

In Romania, Oil and Gas industry is a very important economical branch as it represents the most significant source of oil production in Central and Eastern Europe and also a key oil importer due to country's geographical position, ports' accessibility via Black Sea and states' oil transportation systems. However, the economic crisis and the internal political changes have determined a decrease in terms of Oil and Gas

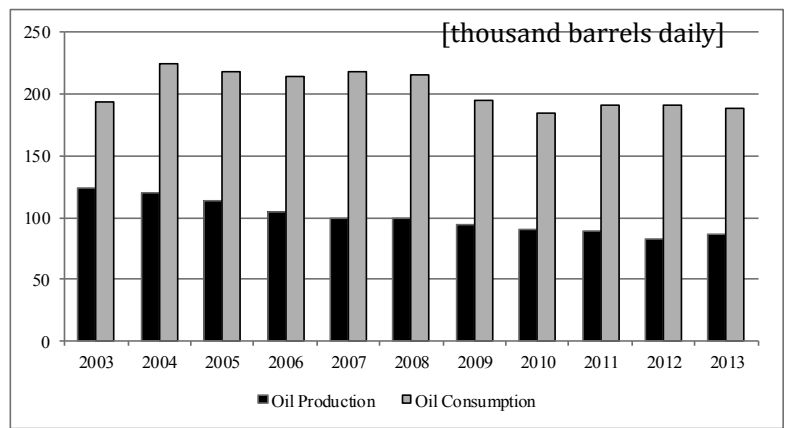

a production and consumption after 2008, as shown below (Fig. 1) (BP Statistical Energy Survey, 2014).

Recent history has shown that major accidents such as Bhopal disaster, Texas City Refinery explosion, Piper Alpha disaster, Macondo Deep Water Horizon blowout have been the proper trigger for companies operating with inflammable hydrocarbon products to allocate substantial effort to improve the operational barriers regarding process safety practices, environment protection

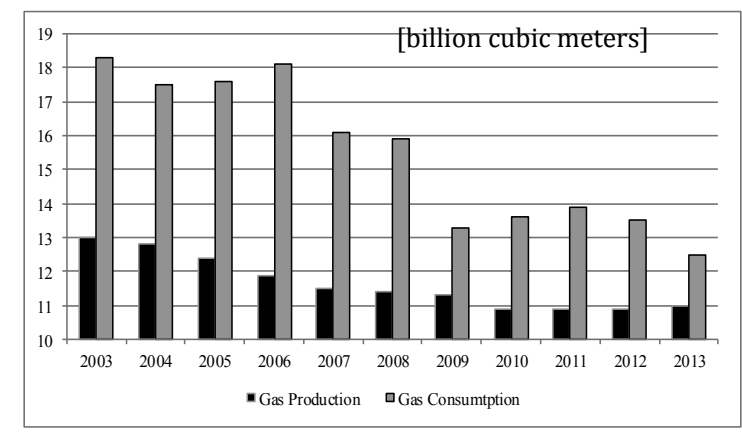

b

Fig. 1. (a) Oil production and consumption in Romania, 2003-2013; (b) Gas production and consumption in Romania (BP Statistical Energy Survey, 2014) 
and community's welfare stability (Union Carbide Corporation, 2014; U.S. Chemical Safety and Hazard Investigation Board, 2005; Macalister, 2013; Deepwater Horizon Study Group, 2011).

With public interest regarding fossil fuels at an all-time high, any misstep on the part of oil \& gas companies can result in significant damage to their reputation, which may ultimately lead to the cessation of activities altogether.

Therefore, this particular study meets the growing challenge that companies operating in this sector face - that is of striking a very delicate balance between maximizing safety precautions whilst running minimal operating costs.

The purpose of the paper is to conduct an analysis of the exposure that these companies face with respect to the object of their activity, considering the increasingly higher concern from public opinion regarding the integrity of operations from a health, safety and environmental point of view. The research objectives were firstly to quantify major risks to which oil \& gas companies are subject to within Romania and, secondly, to identify recommendations regarding prevention of major incidents with damaging consequences on companies' reputation.

Companies operating on Oil and Gas Romania market needed to cope with a range of fiscal changes in order to align with the European Union regulations and comply with the national taxation governance. According to KPMG's report (2013), royalties applied on companies producing condensed crude oil vary from $3.5 \%$ for a gross production per quarter less than 10.000 tons to $13.5 \%$ for a level exceeding 100.000 tones. There is also applied $10 \%$ tax to gross income obtained in any operation involving the usage of national transportation systems and/ or oil terminal.

After 2007, Romanian companies had to adapt their business according to a series of new regulations according to European Union directives. Oil and Gas companies had to adjust their way of operating by placing safety on top of their priorities. Amending Directive 2004/34/ EC and Directive 2013/30/EU of the European Parliament and of the Council on safety of offshore oil and gas operations emphasized the importance of protecting and preserving the quality of the environment (Official Journal of the European Union, 2013).
Member States are part of a network entitled "Natura 2000", which into national legislation is Emergency Government Ordinance no. 57/2007, whose aim is to protect natural areas, habitats, flora and fauna, which in Romania have a total coverage of $17 \%$ of country surface (Radu, 2012). Therefore, protecting the environment, alongside employees' safety and social equity (community) are the three major dimensions a company active on Oil and Gas industry should take into consideration for a sustainable development.

As Romania dominates South-eastern Europe, the issues related to companies' image operating on this particular industry have become increasingly important in terms of maintaining a proper relation with key stakeholders. Therefore, unlike other entities active on different markets, the management of risks factors which may negatively affect the reputation of the aforementioned companies has never been more necessary.

Within this context, the scientific literature encompasses a wide range of definitions for the reputational risk concept, but the core idea starts from the difference recorded between expectation and actual experience of an individual. However, the reputational risk is based on the perception of the stakeholders, which in turn is influenced by social background, economic factors, corporate values, laws and regulations and other more (Protiviti, 2013).

According to US Federal Reserve (1995) "reputational risk is the potential that negative publicity regarding an institution's business practices, whether true or not, will cause a decline in the customer base, costly litigation or revenue reductions." Moreover, Diermeier (2008) asserted that reputation management is impossible if the 3 "C"s arise, that is: lack of Control, limited Credibility and overwhelming Complexity, emphasizing the importance of properly understanding the psychological component when assessing the risk factors to reputation.

Moreover, the Reputation Institute (2008) submitted a reputation value-cycle which comprises supportive behaviours, financial performance, business strategy, corporate initiatives and perceptions, and reputation, highlighting in this manner the intertwining of risk management with the organization's different areas, from strategic to operational level. 


\section{MATERIALS AND METHODS}

The methodology involved secondary research tools and a qualitative assessment of the reputational risk of oil companies operating in Romania due to their economical major role on the national business market. Moreover, the wide range of stakeholders involved has divergent interests generating new sources of risks, which may directly influence the company's reputation and business continuity.

The sample of the study was comprised of nine companies operating in the following sectors: production, refinery, distribution and transport of hydrocarbons products due to their economic importance for the GDP of Romania and for their operational coverage nationwide (Petrescu, 2014; Economica, 2014; Focus Energetic, 2014; Rompetrol, 2014)

The qualitative assessment was concluded taking into consideration the risks' potential effects and the probability of occurrence of the aforementioned risks on the following impact levels (Tab.1).

The criteria for impact assessment of reputational risks were adapted from BP' annual report (2013) and the risks analysis was based on a scale comprising three grades of severity: low, medium and high, defined as shown below (Tab. 2).

The assessment criteria was established by the authors considering only the publicly available data on annual reports of oil companies. These reports made possible to identify the criteria based on the main challenges companies have faced during their annual activity and on what were the major concerns of these aforementioned companies regarding the health and safety, community and environment ( BP Annual Report 2013, pg. 53, OMV Petrom, 2012, pg. 8).
In order to quantify the impact level for assessment criteria, the authors considered that the Romanian oil companies are complying with HSSE (Health. Safety. Security. Environment) standards, which means their goal is zero fatalities and zero loss time injury rate (low impact). Also, based on the historical recorded data regarding number of fatalities and loss time injury rate, the authors established the medium and high impact, since there is not available any official description of these impact levels.

Therefore, the values described in Table 2 have been chosen based on industry-wide benchmarking and adapted from the BP Annual Report, as it is one of the largest international integrated oil \& gas companies.

The probability of appearance of the event was also assessed using on a low-medium-high scale based on the quality of historical data available and previous precedents recorded.

Health and safety, community and environment are intertwining; therefore sustainability can be achieved only by focusing on all three dimensions simultaneously. The risk analysis conducted in this study implied risks identification and qualitative assessment of these aforementioned risks taking into consideration the four major segments corresponding to the degree of processing of hydrocarbons: exploration \& production, transportation, refining and distribution.

\section{RESULTS AND DISCUSSION}

When considering the Oil \& Gas industry, the literature talks of the upstream segment, which involves hydrocarbon exploration \& production, the midstream segment, which includes transportation of stabilized crude hydrocarbons

Tab. 1. Identification of impact levels

\begin{tabular}{ll}
\hline Impact level & Description \\
\hline Health \& Safety & $\begin{array}{l}\text { Negative effects on individuals' safety, health and welfare as direct or indirect result } \\
\text { of company's activity (including employees and third party entities involved in the } \\
\text { company's operations) }\end{array}$ \\
\hline Community & $\begin{array}{l}\text { Negative effects on employment rate, education level, families' lifestyle, cultural activities } \\
\text { etc. recorded within a community }\end{array}$ \\
\hline Environment & $\begin{array}{l}\text { Negative effects on atmosphere, water, soil, flora or fauna within a particular area as } \\
\text { direct or indirect result of company's activity }\end{array}$ \\
\hline
\end{tabular}


Tab. 2. Assessment criteria description (adaptation from BP Annual Report, 2013; OMV Petrom, 2012)

\begin{tabular}{|c|c|c|c|c|}
\hline \multirow{2}{*}{\multicolumn{2}{|c|}{$\begin{array}{c}\text { Criteria } \\
\text { Low }\end{array}$}} & \multicolumn{3}{|c|}{ Impact } \\
\hline & & Medium & High & \\
\hline \multirow[t]{3}{*}{ HS } & Health and Safety & & & \\
\hline & $\begin{array}{l}\text { Number of fatalities (number } \\
\text { of accidents resulted with } \\
\text { employee's death) }\end{array}$ & 0 & 1 & $>1$ \\
\hline & $\begin{array}{l}\text { Loss Time Injury Rate (number } \\
\text { of incidents with temporary loss } \\
\text { of working capacity per million } \\
\text { hours per year) }\end{array}$ & 0 & $<0.49$ & $>0.5$ \\
\hline \multirow[t]{3}{*}{$\mathrm{C}$} & Community & & & \\
\hline & $\begin{array}{l}\text { Traffic, noise, dust level due to } \\
\text { companies' activity (changes } \\
\text { recorded due of company's } \\
\text { activity) }\end{array}$ & $\begin{array}{c}\text { Insignificant } \\
\text { (minimal damage } \\
\text { to community's } \\
\text { welfare) }\end{array}$ & $\begin{array}{c}\text { Disruptive } \\
\text { (acknowledged } \\
\text { discomfort of commu- } \\
\text { nity' members) }\end{array}$ & $\begin{array}{l}\text { Critical (high damage } \\
\text { of community } \\
\text { welfare) }\end{array}$ \\
\hline & $\begin{array}{l}\text { Complaints recorded from } \\
\text { community members }\end{array}$ & $\begin{array}{l}\text { Isolated } \\
\text { complaints }\end{array}$ & $\begin{array}{l}\text { Complaints solved } \\
\text { amiably }\end{array}$ & $\begin{array}{l}\text { Significant fines and } \\
\text { long-term lawsuits }\end{array}$ \\
\hline \multirow[t]{4}{*}{ E } & Environment & & & \\
\hline & Total affected area & $\begin{array}{l}\text { Reduced (isolated } \\
\text { on site) }\end{array}$ & $\begin{array}{l}\text { Moderate (one } \\
\text { location) }\end{array}$ & $\begin{array}{c}\text { Critical (exceeds one } \\
\text { location) }\end{array}$ \\
\hline & Wastewater consumption & Tolerable & Moderate & Critical \\
\hline & $\begin{array}{l}\text { Level of chemical agents release } \\
\text { (pollutants) }\end{array}$ & Tolerable & Moderate & Critical \\
\hline \multicolumn{5}{|c|}{$\mathrm{HS}, \mathrm{C}, \mathrm{E}$} \\
\hline & Media attention coverage & $\begin{array}{c}\text { No media attention } \\
\text { or easily amended } \\
\text { local media } \\
\text { attention }\end{array}$ & $\begin{array}{l}\text { Media attention } \\
\text { broadcasted locally } \\
\text { and nationally }\end{array}$ & $\begin{array}{l}\text { National and } \\
\text { international media } \\
\text { attention with long- } \\
\text { term negative effect }\end{array}$ \\
\hline & $\begin{array}{l}\text { Timespan of incident's public } \\
\text { awareness due to negative } \\
\text { publicity }\end{array}$ & $\begin{array}{l}\text { Short-term } \\
\text { (max. } 3 \text { months) }\end{array}$ & $\begin{array}{l}\text { Medium-term } \\
\text { (3-12 months) }\end{array}$ & $\begin{array}{l}\text { Long-term } \\
\text { (exceeds } 12 \text { months) }\end{array}$ \\
\hline
\end{tabular}

Tab. 3. Oil and Gas industry segments based on the degree of processing of hydrocarbons (PSAC Working Energy, 2014; Danilov, 2014; Petrescu, 2013)

\begin{tabular}{|c|c|c|}
\hline Segment & Definition & Description \\
\hline Upstream & $\begin{array}{l}\text { Exploration } \\
\text { \& Production }\end{array}$ & $\begin{array}{l}\text { The production segment in the hydrocarbon life-cycle is the one concerned with the } \\
\text { extraction of product from previously-drilled underground wells, as well as primary } \\
\text { treatment (separation in case of oil and drying / decontamination for gas) of this } \\
\text { product }\end{array}$ \\
\hline Midstream & $\begin{array}{l}\text { Transpor- } \\
\text { tation }\end{array}$ & $\begin{array}{l}\text { The transportation segment is dominated by companies where the State holds } \\
\text { the majority of shares. These companies operate large networks of pipelines } \\
\text { that connect the major producing areas of the country to refineries (oil) or gas } \\
\text { distribution companies. }\end{array}$ \\
\hline Downstream & Refining & The overall processing capacity accounts for 14,8 million tones/year of crude oil. \\
\hline Downstream & Distribution & $\begin{array}{l}\text { The diesel/gasoline station network in Romania accounted for } 1386 \text { stations in } \\
2013 .\end{array}$ \\
\hline
\end{tabular}


and occasionally storage and sale and the downstream segment, consisting of refining and subsequent distribution of processed petroleum and gas products (Tab. 3) (PSAC Working Energy, 2014; Danilov, 2014; Petrescu, 2013).

The main findings of the present paper consisted in identifying the reputational risk factors in the fields of health and safety, community and environment, as well as the organisation mitigation strategies aiming to reduce both the impact of their operations on the environment and consolidate a positive public opinion, as presented in the table below (Tab 4).

The primary risks identified within this paper are those most often encountered within the industry. The analysis performed refers to the immediate effects of the events in their respective categories - e.g. very rarely does a major accident event lead to merely pollution of the air, however, for the purposes of the present study, the scope was restricted just to air pollution.
Occupational Health and Safety are programs regarding not only employees' security but also third party entities involved in the company's operations that might be affected by the workplace environment (Alli, 2008). These aforementioned programs enclose general and specific liabilities, and any breach of these obligations may damage company's reputation.

Therefore, in the case of Occupational H\&S breaches, the highest probability of occurrence is attributed to the Production / Transportation / Distribution sector. Risk factors may include Health and Safety procedure infringement due to concealed information regarding work hazards, especially in the case of new workers or employed who are re-entering the work place; psychological discomfort/ physical suffering which enable the worker to focus on the job (Workcover, 2012).

This is so primarily due to the geographical expanse of these sectors: wells are located throughout the country, with the landscape varying

Tab. 4. Risk qualitative assessment

\begin{tabular}{|c|c|c|c|c|c|c|c|c|}
\hline \multirow{2}{*}{ Risk } & \multirow{2}{*}{ Source } & \multicolumn{3}{|c|}{ Probability } & \multicolumn{3}{|c|}{ Impact } & \multirow{2}{*}{$\begin{array}{l}\text { Risk Preventive/ Mitigating } \\
\text { Actions }\end{array}$} \\
\hline & & HS & $\mathrm{C}$ & $E$ & HS & $\mathrm{C}$ & $E$ & \\
\hline \multirow[t]{2}{*}{$\begin{array}{l}\text { Occupational } \\
\text { H\&S breaches }\end{array}$} & $\begin{array}{l}\text { Production/ } \\
\text { Transportation/ } \\
\text { Distribution }\end{array}$ & M & N/A & $\mathrm{N} / \mathrm{A}$ & $\mathrm{L}$ & N/A & N/A & \multirow{2}{*}{$\begin{array}{l}\text { Implement precise and } \\
\text { thorough work instructions } \\
\text { and operating procedures for } \\
\text { personnel and equipment }\end{array}$} \\
\hline & Refinery & $\mathrm{L}$ & $\mathrm{N} / \mathrm{A}$ & $\mathrm{N} / \mathrm{A}$ & $\mathrm{L}$ & $\mathrm{N} / \mathrm{A}$ & $\mathrm{N} / \mathrm{A}$ & \\
\hline \multirow{2}{*}{$\begin{array}{l}\text { Process Safety } \\
\text { breaches }\end{array}$} & $\begin{array}{l}\text { Production/ } \\
\text { Transportation/ } \\
\text { Distribution }\end{array}$ & M & $\mathrm{L}$ & M & $\mathrm{M}$ & M & M & \multirow{2}{*}{$\begin{array}{l}\text { Conduct integrity assessment } \\
\text { of plant / facilities; } \\
\text { Review operating policy and } \\
\text { conduct studies to ensure all } \\
\text { processes remain within safe } \\
\text { operating limits. }\end{array}$} \\
\hline & Refinery & $\mathrm{L}$ & $\mathrm{L}$ & $\mathrm{L}$ & $\mathrm{H}$ & $\mathrm{H}$ & $\mathrm{H}$ & \\
\hline \multirow{4}{*}{$\begin{array}{l}\text { Damage } \\
\text { of crops / } \\
\text { property due to } \\
\text { contamination } \\
\text { of soil / water }\end{array}$} & Production & $\mathrm{N} / \mathrm{A}$ & $\mathrm{L}$ & M & $\mathrm{N} / \mathrm{A}$ & M & M & \multirow{4}{*}{$\begin{array}{l}\text { Adhere to strict operating } \\
\text { procedures to limit fluids, } \\
\text { other than clear water to } \\
\text { be unintentionally released } \\
\text { from a process unit due to } \\
\text { spills, ruptured crude oil pipe, } \\
\text { overflowing gasoline tank. }\end{array}$} \\
\hline & Refinery & $\mathrm{N} / \mathrm{A}$ & $\mathrm{L}$ & $\mathrm{L}$ & $\mathrm{N} / \mathrm{A}$ & $\mathrm{H}$ & M & \\
\hline & Transportation & $\mathrm{N} / \mathrm{A}$ & $\mathrm{L}$ & M & $\mathrm{N} / \mathrm{A}$ & $\mathrm{H}$ & $\mathrm{H}$ & \\
\hline & Distribution & $\mathrm{N} / \mathrm{A}$ & $\mathrm{L}$ & M & $\mathrm{N} / \mathrm{A}$ & M & M & \\
\hline \multirow{4}{*}{$\begin{array}{l}\text { Air pollution } \\
\text { due to major } \\
\text { accident events }\end{array}$} & Production & $\mathrm{N} / \mathrm{A}$ & $\mathrm{L}$ & $\mathrm{L}$ & $\mathrm{N} / \mathrm{A}$ & $\mathrm{M}$ & M & \multirow{4}{*}{$\begin{array}{l}\text { Process reliability in order to } \\
\text { detect events connected to a } \\
\text { facility in terms of hazardous } \\
\text { air pollutants. }\end{array}$} \\
\hline & Refinery & $\mathrm{N} / \mathrm{A}$ & $M$ & $M$ & $\mathrm{~N} / \mathrm{A}$ & $\mathrm{H}$ & $\mathrm{H}$ & \\
\hline & Transportation & $\mathrm{N} / \mathrm{A}$ & $\mathrm{L}$ & $\mathrm{L}$ & $\mathrm{N} / \mathrm{A}$ & $\mathrm{H}$ & $\mathrm{H}$ & \\
\hline & Distribution & $\mathrm{N} / \mathrm{A}$ & $\mathrm{L}$ & $\mathrm{L}$ & $\mathrm{N} / \mathrm{A}$ & M & M & \\
\hline
\end{tabular}

Legend: HS= Health and Safety; C=Community; E-Environment; L=Low; M=Medium; H=High; N/A=Not applicable. 
from flat plains to mountainous regions and are connected to gathering points by flow lines which cross valleys, forests etc, but also due to the diversity of the equipment, which may result in errors on behalf of the operators / maintenance personnel. By contrast, in a refinery environment, the worker crews operate in a much more familiar surroundings: they already know where the trip hazards are, they have been to that section of the facility before, as opposed to someone who has to fix a ruptured pipeline in the middle of the forest, at night. This is not to say that tripping - for example - does not happen in refineries: it does, but due to the nature of the activity, such events are a lot less frequent than in the upstream segment. (Alli, 2008)

Process safety breaches imply risk factors such as fire, explosion, chemical agents' spills, leaks, and equipment malfunction (Shell, 2010). Therefore, their impact may occur to all four stages, but specifically, this type of risk is associated to refineries as these facilities operate with highly inflammable hazardous materials.

In addition, for process safety breaches, a higher frequency of occurrence is allocated to the upstream sector, for the same reasons as discussed in Occupational $\mathrm{H}$ \& S. However, the focus shifts from individuals to pieces of equipment / production processes, as well as procedures in place. In the case of refineries, the probability of occurrence is, again, relatively low, since this segment of activity is quite well established within this country, the processes are managed accordingly and the personnel employed is specialized.

Soil, water or air pollution are related to major accidents, as they have potential to cause multiple fatalities and damage the biodiversity within a region, oftentimes irreparably. Pollution is a sensitive topic for oil and gas companies due to their basic activity and their vast geographical working sites 'coverage nationwide. Therefore, internal measures regarding equipment replacement and employees' security were no longer enough and investing in an amiable relationship with the community became crucial.

Regarding the contamination of soil/water due to spills, higher probabilities are associated to the upstream segment where, because of the nature of the geography, flow lines /pipelines stretch for many thousands of kilometers with spills of product of relatively low volumes in the production segment, but high volumes in the transportation segment. Therefore, the transportation and distribution have a more severe impact on the environment in case of spills/leakage.

Based on the qualitative assessment of the risk factors and according to the international technical documentations, the authors propose a series of recommendations, which can secure the reputation of companies operating on oil industry such as:

Studies on hazard and operability (HAZOP technique) aim to analyse the plant from the operational points of view and to thoroughly assess how the facilities will react in case of abnormal operating conditions, by looking at potential initiating causes and safeguards. (The Institution of Engineering and Technology, 2012)

In-depth analysis of layers of protection (LOPA technique) which allows for minute investigation of a segment of the plant that the HAZOP team feels should be more thoroughly addressed. Therefore, this analysis relies on inputs from the HAZOP study. (Summers, 2002)

Failure modes and effects analysis (FMEA technique) aim to analyse the facility by looking at its constituent pieces of equipment, analysing which functions they perform, how they can fail to perform their functions, what causes this failure. (The Institution of Engineering and Technology, 2012).

Finally, the strategies for detracting reputational risk involve a twofold approach: "insideout", which implies prevention and mitigation of risks within the organisation (Tab. 4), and "outside-in", which involves undertaking Corporate Social Responsibility programs (Tab. 5) in order to strengthen the stakeholders 'trust (ACE, 2013). As business' sustainability can be achieved only by considering all stakeholders, in the following examples of CSR activity types, the beneficiaries vary from employees and customers to community members involved in the company's operations.

The efficiency of CSR programs and internal sustainable development activities can be assed comparing the values of the indicators recorded in 2008 with the most recent data published. For instance, in 2013 in comparison with the reference year, OMV Petrom reported $80 \%$ less fatalities, 
Tab. 5. Types of CSR activities undertaken by oil and gas companies

\begin{tabular}{|c|c|c|}
\hline Health \& Safety & Community & Environment \\
\hline $\begin{array}{l}\text { - accidents prevention trainings } \\
\text { regarding pipeline damage; } \\
\text { - process reliability; } \\
\text { - campaign for preventing } \\
\text { electrocution accidents; } \\
\text { - campaign regarding hazardous } \\
\text { substances management; }\end{array}$ & $\begin{array}{l}\text { - donations for the first centre } \\
\text { of diagnosis and treatment of } \\
\text { lymphatic cancer; } \\
\text { - computers donations for the } \\
\text { paediatric clinic; } \\
\text { - rehabilitation of parks and other } \\
\text { leisure areas; }\end{array}$ & $\begin{array}{l}\text { - trees planting and activities for rare } \\
\text { birds' protection; } \\
\text { - domestic water treatment by } \\
\text { harnessing renewable energy } \\
\text { sources at a city hospital; } \\
\text { - high-tech water treatment stati- } \\
\text { ons for waste obtained from } \\
\text { technological processes. }\end{array}$ \\
\hline
\end{tabular}

88\% less incidents with temporary loss of working capacity, and 59\% less frequency of accidents with lost working time per million hours worked and there were also recorded less greenhouse gas emissions, which decreased by $3.4 \%$ (million tons $\mathrm{CO}_{2}$ equivalent). The overall relation with the community has been improved due to the annual contribution, which in 2013 accounted for 5 million Euro and the high number of employees, which has increased by $41 \%$ compared to 2008 (OMV Petron Annual Report, 2013).

\section{CONCLUSION}

Environmental pressure on oil and gas companies has significant effect on the manner in which these entities operate and failing to comply with these ever stricter environmental policies may very well result in irreparable damage to the image of the company.

Due to the much more complex processes which take place in refineries, the impact of a breach in process safety is a lot more severe, both for the $\mathrm{H} \& \mathrm{~S}$ of the employees, as well as the communities (particularly taking into consideration the fact that, in Romania, refineries are relatively close to cities) and environmental impact. In the refining segment, since the processes themselves involve the use of reactants in addition to hydrocarbons, the impact of leakages is more severe, but the probability of occurrence of leakages resulting in pollution of soil and / or water is low.

However, unlike the view expressed by the annual reports issued by oil companies active in Romania (OMV Petrom 2013, Shell 2010) and the approach of current scientific papers (Saltaji, 2014; Polsterer 2012) in regards to the reputational threats, the present paper comprises all stages of risk management process, not only the identification phase and shows the link between a particular risk factor with damaging effect on reputation and the industry segments based on the type of hydrocarbon processing operations and the severity of risk occurrence for each level of impact (health and safety, community and environment).

As the business sector itself is not subject to a very sympathetic overall perception, an organisation operating within this particular industry sector must undertake a higher effort to detract public suspicion and to maintain a favourable relation with the community. The transition from reputational risk to reputational advantage is oftentimes costly and frequently involves process adjustment and procedure revision in order to comply with the requirements.

Even thought, the limitation of the present paper arises from restrictive access to information and the fact that the entire study was based on publicly available data on companies' private websites, oil and gas dedicated sites and public annual reports, the results obtained from the risk analysis enable companies operating on Oil and Gas market to enhance their current understanding of the way risks impact the different levels of activity of this industry through the qualitative analysis undertaken by the authors.

Acknowledgments. The work has been funded by the Sectorial Operational Program Human Resources Development 2007-2013 of the Ministry of European Funds through the Financial Agreements POSDRU/159/1.5/S/134398.

\section{REFERENCES}

1. ACE (2013). European Risk Briefing: Reputation at Risk. Available: http://www.acegroup.com/global-assets/ documents/Europe-Corporate/Thought-Leadership/ ace_reputation_at_risk_july_2013.pdf [date accessed 14.10.2014] 
2. Alli BO (2008). Fundamental principles of occupational health and safety. International Labour Office. Geneva 3-21.

3. BP (2013). Annual report and forum: Building a stronger safer BP. Available: http://www.bp.com/content/ $\mathrm{dam} / \mathrm{bp} / \mathrm{pdf} /$ investors/BP_Annual_Report_and_ Form_20F_2013.pdf [date accessed 02.09.2014].

4. BP (2014). Statistical Review of World Energy. Available: http://www.bp.com/en/global/corporate/about-bp/ energy-economics/statistical-review-of-world-energy. html [date accessed 02.09.2014].

5. Conpet(2014). Responsibility towards environment. Available: http://www.conpet.ro/resp_mediu.html [date accessed: 20.08.2014]

6. Danilov A (2014). The evolution of Romanian oil industry during 1857-1945. Available:http://www.historia.ro/ exclusiv_web/general/articol/evolutia-industriei-petroliereromanesti-perioada-1857-1945 [date accessed: 06.09.2014].

7. Deepwater Horizon Study Group (2011). Final report on the Investigation of the Macondo Well Blowout. Available: http://ccrm.berkeley.edu/pdfs_papers/bea pdfs/dhsgfinalreport-march2011-tag.pdf [date accessed 13.10.2014]

8. Diermeier D (2008). Reputational risk: Measuring and managing reputational risk. In Risk Management, Issue12 20-22.

9. Economica (2014). Searches atPetrotel Refinery. Available: http://www.economica.net/perchezitii-la-rafinariapetrotel-ploiesti_88848.html [date accessed:14.10.2014]

10. Federal Reserve (1995). Rating the Adequacy of Risk Management Processes and Internal Controls at State Member Banks and Bank Holding Companies. Available: http://www.federalreserve.gov/boarddocs/ srletters/1995/sr9551.htm [date accessed: 04.09.2014]

11. Focus Energetic (2014). Available: http://www.focusenergetic.ro/kazahii-de-la-petromidia-cumpara-incao-rafinarie-in-europa-18554.html [date accessed: 14.10.2014]

12. The Institution of Engineering and Technology (2012). Hazard and Operability Studies. Health and Safety Briefing, no. 46 a.

13. The Institution of Engineering and Technology (2012). Failure Modes and Effects Analysis. Health and Safety Briefing, no. 26 a.

14. KPMG (2013). A Guide to Romanian oil and gas taxation. Available: http://www.kpmg.com/RO/ en/IssuesAndInsights/ArticlesPublications/news/ Documents/ENRTax_ENGLISH_dec2013.pdf [date accessed 26.08.2014]

15. Macalister T. (2013). Piper Alpha disaster: how 167 oil rig workers died. Available: http://www.theguardian.com/ business/2013/jul/04/piper-alpha-disaster-167-oil-rig [date accessed 13.10.2014]

16. Official Journal of the European Union (2013). Directive 2013/30/EU of the European Parliament and of the Council of 12 June 2013 on safety of offshore oil and gas operations and amending Directive 2004/35/EC 66-106.

17. OMV Petrom (2013). Annual Report. Available: http://petromraport2013.webstyler.ro/files/library/ Raport\%20anual\%20Petrom\%20Grup\%202013.pdf [date accessed 26.08.2014]

18. OMV Petrom (2014). Report of community involvement 2013. Available: http://www.taraluiandrei.ro/implicarea- petrom/raport-de-implicare-in-comunitate-2013 [date accessed: 07.09.2014].

19. Petrescu R (2013). Oil station map in Romania. Available: http://www.zf.ro/auto/harta-benzinariilor-din-romaniacum-si-au-impartit-marii-petrolisti-tara-11269175 [date accessed: 06.09.2014].

20. Petrescu R (2014) Petrom has completed a 600 million Euro investment at Petrobrazi. Available: http://www. zf.ro/zf-24/petrom-a-finalizat-investitii-de-600-mileuro-la-petrobrazi-programul-initial-era-de-750-mileuro-si-viza-extinderea-capacitatii-13261747 [date accessed:14.10.2014]

21. Protiviti (2013). The Bulletin: Ten keys to managing reputation risk. Available: http://www.protiviti.com/enUS/Documents/Newsletters/Bulletin/The-Bulletin-Vol5-Issue-2-10-Keys-Managing-Reputation-Risk-Protiviti. pdf [date accessed 02.09.2014]

22. PSA Working Energy (2014). Industry overview. Available: http://www.psac.ca/business/industry-overview/ [date accessed: 06.09.2014]

23. Polsterer N (2012). OMV, the UN Global Compact and Human Rights: From Signature to implementation. Available: https://www.unglobalcompact.org/ system/attachments/714/original/E3D2C114-CFFC4584-B38B-09B8B5E87A9D.pdf?1262614056 [date accessed:14.10.2014]

24. Radu V (2012). Aspects of the Environmental Regulatory Framework Impacting Upstream Oil and Gas Industry. Romania's Framework for Oil \& Gas Development: Current status, present and future challenges. Bucharest.

25. Reputation Institute (2008). Corporate reputation management. Available: http://www.reputationinstitute. com/events/10Apr08_Reputation_Management_Munich. pdf [date accessed 26.08.2014]

26. Rompetrol (2013).Together for each and everyone. Available: http://www.impreunapentrufiecare.ro/ [date accessed: 20.08.2014].

27. Rompetrol (2014). Available http://www.rompetrol. com/ro/rompetrol-rafinare [date accessed: 14.10.2014]

28. Saltaji IMF (2014). Corporate Governance in Eastern Europe: Case of Romania and Russian Federation. Theoretical and applied economics, vol. XXI, no. 4 (593), pp. 99-112.

29. Shell (2010). Process safety in Shell. Available: http://s05. static-shell.com/content/dam/shell/static/environmentsociety/downloads/safety/process-safety-inshelllr.pdf [date accessed 07.09.2014]

30. Summers A. (2002). Introduction to Layer of protection analysis. May Kay O'Conner Process Safety Centre Symposium, Texas A\&M University. Available: https:// www.jlab.org/accel/ssg/safety/LAYER\%2 00F\%20 PROTECTION\%20ANALYSIS.pdf

31. Union Carbide Corporation (2014). Bhopal Gas Tragedy Information. Available: http://www.bhopal.com/. [date accessed 13.10.2014]

32. U.S. Chemical Safety and Hazard Investigation Board (2005). Investigation report: Refinery explosion and fire. Available: http://www.csb.gov/assets/1/19/ csbfinalreportbp.pdf [date accessed 13.10.2014]

33. Workcover (2012). Work Health and Safety. Available: http://www.workcover.nsw.gov.au/newlegislation2012/ Pages/default.aspx [date accessed: 07.09.2014]. 